\title{
Feeding the reactors: potentials in re-cycled organic fertilisers
}

\author{
Anne-Kristin Løes (D)
}

Received: 15 May 2020 / Accepted: 27 May 2020 / Published online: 10 June 2020

(C) The Author(s) 2020

\begin{abstract}
There is a large and growing interest in producing proteins, oils and other important commodities in bioreactors. Mineral fertilisers, especially nitrogen $(\mathrm{N})$ and phosphorus (P), are used to supply the living organisms with nutrients, and for growing of fungi, carbon must be applied from sugar or starch products. This input-for-output approach does not contribute to cycling of nutrients and organic matter in the society. Organic* ${ }^{1}$ agriculture has a strong interest in recycled fertilisers and best utilisation of organic materials, and appliccable products should be developed not only for use in agricultural fields but also for other purposes, such as hydroponics, aquaponics and bioreactors. Animal bones and precipitated struvite from waste water are examples of materials which may be applicable in bioreactors. Containing easily available $\mathrm{N}$ and $\mathrm{P}$, recent studies have shown that these materials are valuable for amendment of soil fertility and crop productivity in land-based agriculture. Studies should be initiated to design bioreactors utilising locally available sources of nutrients and organic matter, to make the bioreactors more sustainable and develop organic* farming systems in a context of landless farming.
\end{abstract}

\footnotetext{
${ }^{1}$ To distinguish between the term "organic" as in certified organic farming, and "organic" as in soil organic matter, the first notion will be indicated with an asterisk $(*)$.
}

A.-K. Løes $(\bowtie)$

Norwegian Centre for Organic Agriculture, Tingvoll, Norway e-mail: anne-kristin.loes@norsok.no
Keywords Nitrogen · Phosphorus · Recycled fertilisers · Struvite $\cdot$ Bioreactor

\section{Introduction}

Human populations grow, and undisturbed environments decline. Urbanisation, salinisation, desertification, rising sea levels, floods and erosion pose significant threats to the global capital of cultivated land. Options are sought and required, to produce food and feed with other methods than traditional cultivation of agricultural land, and natural collection. Landless food systems are called for, e.g. in a paper aiming at securing the availability of food in Africa in 2100 by more circular and sustainable food chains (Rahmann et al. 2019). The authors propose a combination of landless and land-based food production as the last, and most important, out of totally 10 actions towards this valuable aim. The main idea is to establish a system of bioreactors to circulate nutrients and produce calories (food ingredients) for food and feed. Microalgae and fungi, especially yeast, are the most relevant organisms to be grown in bioreactors. Growing yeast in closed systems is a well-established industry. Fungi are dependent on supply of a source of fixated carbon (e.g. sugar), whereas microalgae fixate carbon from the air with light as energy source. Both groups of organisms are dependent on supply of some elements like nitrogen $(\mathrm{N})$ and phosphorus (P).

Strains of yeast have been cultivated since about 1900 , and strains may be traditionally bred, or 
genetically modified, for different purpose. For instance, it is possible to produce "animal-free milk" from a strain designed for this purpose, by inserting genes for milk production into the yeast fungal cell, multiply the strain, add nutrients and sugar required for fermentation and filtering off the requested product (Kowitt 2017). Research on enzymes being able to degrade complex types of organic matter such as lignin to sugars is vigorous, and proteins for feeding fish are planned to be produced from wood (Øverland and Skrede 2017). Some yeast species produce filaments which may be useful for extracting food and feed-like materials from the fermentation broths. A product called mycoprotein is grown in bioreactors from a filamentous type of fungi originally isolated from soil, Fusarium venenatum. The output is a material comparable to minced meat. Mixed with a binding agent from eggs or potatoes, the commercial product "Quorn" is increasingly popular, but also questioned for being far from natural (Blythman 2018). Growing single animal cells in bioreactors is another approach (e.g. JUST meat).

Microalgae have been harvested from natural environments for human consumption, e.g. in pills and cookies, commercially cultivated for human consumption and aquaculture, and broadly studied for technical applications (biofuel) and/or application as food ingredients (protein, lipids, polysaccharides, prebiotics) (Caporgno and Mathys 2018). For this group of organisms, research has so far rather concentrated on utilising various naturally occurring species, than breeding new strains. Species may be harvested for further cultivation both from sea water and fresh water. The sea water species Spirulina platensis, being very high in proteins, has received a special interest (e.g. Lupatini et al. 2017). There is a possibility for utilising wastewater (Lundquist et al. 2010) or salinised drainage water in cultivation systems for microalgae (Bosschaert 2001).

Whereas the interest in producing alternatives to meat, and transforming less valuable organic materials to biofuels, is massive, the interest for combining such approaches with recycling of nutrients from organic waste instead of purified mineral fertilisers is low. The authors of the landless food concept are ambitious: 1 ha of cropland should be replaced by not more than one square meter of bioreactor space (Rahmann et al. 2019). Available cropland should be used for production of high-quality, fresh and edible food items. The food system should be able to produce enough, healthy and affordable food for $11-16$ billion people by 2100 . To be a part of a complete organic* food system, these reactors should be fed by recycled fertilisers and poorly utilised sources of organic matter, being locally available and integrated in a circular economy. Hydroponic and aquaponic growing systems and raising of snails, larvae and other nutritious organisms are other examples of food and feed production which may occur in landless food production, where recycled fertilisers and organic waste may be utilised and upgraded. Such production methods are out of the scope of this paper.

Landless approaches to food production challenge the concept of naturalness, emphasised by many environmentally concerned consumers and developed, e.g. in certified organic* food production. As discussed by Blythman (2018), a lot of processing and food additives are required between the reactor and the final consumer. On the other side, a better recycling of nutrients and increasing food security for all are challenges where organic* food production needs better solutions to design a complete food system which can contribute significantly to sustainable development.

In the present paper, basic requirements for fertilisation of organisms produced in bioreactors will be presented, focussing on microalgae and yeasts. Based on results and experiences with various recycled fertiliser materials and using animal bones and struvite from sewage as examples, it will then be discussed how we may design landless food reactors adapted to such sources of nutrients, rather than conventional mineral fertilisers. The aim of the paper is to present relevant research findings and discuss how they may contribute to realise a system of food and feed producing bioreactors required in a landless food system, utilising recycled nutrients and sources of organic matter.

\section{Conditions for growing microalgae and yeast fungi in bioreactors}

Required elements

Terrestrial crop plants acquire carbon $(\mathrm{C}$, as carbon dioxide, $\left.\mathrm{CO}_{2}\right)$ and oxygen $\left(\mathrm{O}_{2}\right)$ from the air. They acquire hydrogen from water $\left(\mathrm{H}_{2} \mathrm{O}\right)$ and essential macro-minerals nitrogen $(\mathrm{N})$, phosphorus $(\mathrm{P})$, potassium $(\mathrm{K})$, calcium $(\mathrm{Ca})$, magnesium $(\mathrm{Mg}$ ) and sulphur $(\mathrm{S})$ from the soil. Legume plants can also assimilate $\mathrm{N}_{2}$ from the air. Additionally, a range of microminerals (boron $(\mathrm{B})$, chloride $(\mathrm{Cl})$, copper 
$(\mathrm{Cu})$, iron (Fe), manganese (Mn), molybdenum (Mo), nickel (Ni) and zink ( $\mathrm{Zn})$ ) are required.

For microalgae, the nutrient demand is somewhat different. The basic mineral requirements are equal for all species of microalgae and comprise N, P and carbon (C) (Khan et al. 2018). Some marine microalgae species also require silicon $(\mathrm{Si})$ as a macronutrient. Microalgae demand B, cobalt (Co), Fe, potassium (K), magnesium $(\mathrm{Mg}), \mathrm{Mo}, \mathrm{Mn}$ and $\mathrm{Zn}$ in trace amounts for successful growth. Microalgae absorb $\mathrm{O}_{2}$ and $\mathrm{H}_{2}$ from water. The concentrations of available $\mathrm{N}$ in the culture substrate have a strong effect on algal growth. $\mathrm{N}$ limitation may reduce algal growth and biomass productivity but may increase the production of carbohydrates and lipids. The source of carbon can be organic forms, such as glycerol or acetates, or $\mathrm{CO}_{2}$, which may allow for a concurrent carbon sequestration if the gas is well utilised by the algae. However, in practice, this may be difficult to achieve (Slade and Bauen 2013).

For the growing of single cell protein or other compounds from yeast, $\mathrm{N}, \mathrm{P}, \mathrm{S}, \mathrm{Fe}, \mathrm{Cu}, \mathrm{Zn}$ and $\mathrm{Mn}$ are essential elements required, in addition to carbon, oxygen and hydrogen. Sugars are most often used as the $\mathrm{C}$ source, but with the right enzymes available, also much less readily degradable materials such as cellulose and even lignin may be used as raw materials (Bekatorou et al. 2006).

\section{Other conditions}

Microalgae are dependent on a source of energy, either from the sun or artificial light. Commercial production of microalgae occurs in two principally different systems; the raceway pond system, which occurs outdoor in a flat area with good access to sunlight, and the photobioreactor system where the algae are cultivated in transparent tubes or containers in a controlled environment (Slade and Bauen 2013). In both systems, the broth of algae and nutrients must be circulated to avoid sedimentation or clogging. In regions of the world with good access to sunlight, fresh water is commonly a scarce resource and marine species of algae may be a better option. Since controlled environment raising of microalgae is quite expensive, a two-step system where the initial phase of cultivation occurs indoor, and the final growth phase in a cheaper raceway pond may be relevant. Cheap access to $\mathrm{CO}_{2}$ and fertilisers $(\mathrm{N}, \mathrm{P})$ is crucial for economic viability, and plants may well be combined with cleaning of exhaust and waste water to benefit from cleaning gate fees (Lundquist et al. 2010). Most microalgae prefer a temperature arrangement of 15 to $30{ }^{\circ} \mathrm{C}$, and the $\mathrm{pH}$ in the growing media should be $7-$ 9 (Esbroek 2018).

For the production of biomass by yeast cells, no light is required, but the process demands a continuous aeration. While yeasts can grow over a range of temperatures from 0 to $47{ }^{\circ} \mathrm{C}$, the optimum temperature for growth is $20-30^{\circ} \mathrm{C}$. Yeasts favour acid conditions and grow well at pH 4.0-4.5 (Battock and Asam-Ali 1998).

\section{Recycled fertilisers applicable for fertilisation of bioreactors}

One of the characteristics of residual and waste materials of organic origin is that all elements are integrated in tissues which are often easily degradable, and large molecules with characteristics quite different from the soluble salts in mineral fertilisers, or the dissolved nutrients in liquid fertilisers. A "final" treatment of organic waste materials occurs in waste treatment plants, which may be very different across the globe dependent on local conditions and scale. Mixing with soil, composting, anaerobic digestion (fermentation), dumping (in rivers or the sea) and incineration are some major pathways of treatment for solid waste, whereas liquid waste and sludges are commonly treated in water treatment plants or applied to soil. Huge amounts of nutrients and organic matter (carbon) are currently poorly utilised in both small-scale and large-scale treatment systems of organic waste, and there is a conflict between the aims of producing high-quality food with low concentrations of not wanted elements and compounds such as pesticide residues and potentially toxic elements (heavy metals), and the need to maintain soil fertility and avoid polluting the environment with excess nutrients, e.g. by eutrophication (Løes and Adler 2019).

Producing more food and feed nearby the sites where large amounts of organic waste materials are produced may open new possibilities for better utilisation of valuable nutrients and organic matter. However, since organic materials are susceptible to degradation and hence commonly the place of living for a range of organisms, they may be challenging to utilise in a simplistic system where only one type of organism is expected to survive, such as in a bioreactor. Procedures to sanitise the materials before applying them to the reactors may be required. 
For utilisation in a food and feed-grade bioreactor, one option is to apply fertiliser inputs which are also food grade, e.g. derived from food industry. This applies to large volumes, e.g. of bone-rich residues, which have proven to be highly efficient fertilisers for crop plants, being rich in N, P, Ca and other minerals. The challenge would then be to maintain food-grade quality throughout the production chain, e.g. during storage and distribution of the fertilisers.

Another option could be to precipitate minerals such as struvite (magnesium-ammonium phosphate) from waste water, and thereby remove both $\mathrm{N}$ and $\mathrm{P}$ and reduce the environmental load to natural waterbodies. By this chemical processing, very pure minerals are achieved, reducing the risk of contamination, e.g. with bacteria or heavy metals.

Recycled organic fertilisers: sediments from oil and protein extraction

After removal of the commercially available meat parts, cartilage and muscle fibres rich in $\mathrm{N}$ are still present on animal bones, which are also in themselves rich in $\mathrm{N}$, in addition to $\mathrm{P}$ and $\mathrm{Ca}$. Such residues may be grinded and hydrolysed, and food or feed grade oils may be produced, along with food or feed grade soluble proteins. Until now, less use has been made of the remaining sediments, which still contain significant amounts of $\mathrm{N}$ in proteins not dissolved by hydrolysis, plus $\mathrm{Ca}$ and $\mathrm{P}$.

Studies of sediments from grinded bones of laying hens, and white fish (cod, saithe) at NORSØK have shown that plants grow vigorously with such materials applied as fertilisers (Løes 2017; Ahuja and Løes 2019). The growth effect is much more rapid than for calcium nitrate, which is considered as a rapidly available $\mathrm{N}$ fertiliser. This may be due to the concurrent availability of $\mathrm{P}$. However, it may also be that the $\mathrm{N}$ in the animal residues is not necessarily being mineralised into ammonium and/or nitrate but taken up directly by the plants. This is not easy to study in practice, but research has shown that plants may assimilate small organic molecules and not only dissolved ions (Dion et al. 2018).

The potential use of such sediments in a bioreactor needs to be studied. The rapid availability of nutrients in experiments with crop plants indicates that nutrients may become available also in a circulating solution. Microalgae are rich in protein and demand high $\mathrm{N}$ concentrations. The concentration of $\mathrm{N}$ and $\mathrm{P}$ can vary quite substantially, from 5 to $10 \%$ of dry matter for $\mathrm{N}$ and $0.3-1.2 \%$ for $\mathrm{P}$ (Lundquist et al. 2010), and the utilisation efficiency of $\mathrm{N}$ (which may be susceptible to gaseous losses) on average may be assumed to be about 50\% (ibid.).

One option to avoid that bioreactors are filled up with solid particles could be to keep materials like this in nylon bags which the water circulates through. However, this will increase the energy consumption for water circulation.

\section{Recycled mineral fertilisers}

Phosphorus is a scarce resource, which has the ability to circulate in the soil-plant-food-soil continuum with a clever design of farming systems. A significant proportion of the total amount of $\mathrm{P}$ available for such cycling is found in wastewater (sewage; Möller et al. 2018). In some countries, biosolids from sewage are used for soil amendment, but in other countries, such material is incinerated. In biosolids, the $\mathrm{P}$ is often bound by chemicals making the $\mathrm{P}$ very little available for uptake in plants or other organisms. Even with such binding of $\mathrm{P}$, treated wastewater may still contain significant concentrations of $\mathrm{P}$. Hence, there are many reasons to improve the removal of $\mathrm{P}$ from wastewater. $\mathrm{N}$ may be emitted as gas, which reduces the risk of eutrophication. A better option could be to also remove the $\mathrm{N}$ in solid form. Precipitation of struvite implies removal of both $\mathrm{N}$ and $\mathrm{P}$. This mineral is easily solubilised in soil, even if it is not water soluble. Applying this mineral to organically managed soil could be an efficient way to increase $P$ cycling (Rittl et al. 2019), since P is often depleted by long-term organic* management (Cooper et al. 2018).

If conditions can be made for dissolving the salt, struvite may be a very relevant fertiliser to apply in bioreactors. Another option is to combine bioreactors with wastewater treatment, to utilise the capacity of the living organisms to take up $\mathrm{N}$ and $\mathrm{P}$.

\section{Discussion}

Two types of waste materials have been presented here. These materials were selected because they have shown promising effects in recent studies with crop plants, and the author has an up-to-date, hands-on experience with these fertilisers. However, several other materials are available in addition which may be useful for applying 
elements (N, P, K, S, Ca, Mg, micronutrients) and/or organic matter as a source of $\mathrm{C}$. Liquid anaerobic digestate, or liquid animal manure, may be applicable since this material is easy to mix into a fermentation broth or liquid media for microalgae. Digestate from plants treating food waste often comes in a sanitised state, but this status is challenging to maintain since the content of mineral $\mathrm{N}$ and other nutrients is high and there is still much organic material ready for decomposition. Liquid animal manure is far from sterile, but in a system where the growing medium is exposed to solar radiation (such as in a raceway system for microalgae), these organisms may die off rapidly.

As for other innovations, the question of scale is crucial. Organic waste is produced on a small-scale level with individuals and families, on a medium-scale level from catering services, and on a large-scale level in food and feed industry. Bioreactors with yeast or microalgae are likely less robust than, e.g. crop plants towards infectious diseases or suboptimal growing conditions. With their generally short life span, the natural behaviour of these organisms will be to spread vigorously and utilise events of satisfactory conditions for a very rapid growth (e.g. leading to algal blooms), leading to a wave of repeated/further spreading. Crop plants may demand more care and infrastructure (e.g. weed-free soil, water, sunlight, fertilisers), but when established, they have some resistance, e.g. towards diseases and pest attacks, and ability to recover from temporary unfavourable conditions. Hence, bioreactors call for substrates which are easier to handle than, e.g. source-separated household waste which is a very diverse mixture of materials and better suited for a more robust treatment such as anaerobic digestion. The digestate, however, may be suited for application, and the same is valid for compost tea.

The high concentrations of both $\mathrm{N}$ and $\mathrm{P}$ in animal bones (including fish bones), and struvite precipitated from wastewater, match the demand for these elements in both yeast and microalgae. This is interesting, since both these types of recycled fertilisers are poorly balanced with respect to the needs of crop plants (Ahuja and Løes 2019; Rittl et al. 2019), and hence need to be applied only in special cases, e.g. of $\mathrm{P}$ depletion or mixed with other materials. Possibly, bioreactors can be a growing system where these fertilisers fit especially well to the demands of the organisms being grown. However, this needs to be studied in detail.
Until now, staple food produced in bioreactors is still quite rare, but research efforts are extensive. As shown by Lundquist et al. (2010), the infrastructure for bioreactors is costly, and variable costs such as costs for growing substrates (sugar), nutrients and light are significant. Hence, combining such reactors with other purposes, such as cleaning of wastewater, may be beneficial. Since bioreactors demand relatively much $\mathrm{P}$, but less of other macronutrients, the potential of such growing systems to contribute to increase the proportion of $\mathrm{P}$ which enters a cycling instead of an "input-output-lost for cycling" approach is also of high interest.

All in all, it deserves a further consideration, and well-planned studies, to combine ideas from organic* agriculture such as utilising locally available sources of organic matter and nutrients, with technologically advanced growing systems like bioreactors. The author of this paper has never worked with a bioreactor and hence is very much aware that the arguments presented here may be heavily challenged by scientists with other background and perspectives. Possibly, discussions in the upcoming workshop, "Combining land-based organic and landless food production: concept for a sustainable solution for Africa in 2100" in Marrakech, November 14-16, 2019, may contribute to a further development of this very preliminary paper.

Funding Information Open Access funding provided by Norwegian Institute of Bioeconomy Research

Open Access This article is licensed under a Creative Commons Attribution 4.0 International License, which permits use, sharing, adaptation, distribution and reproduction in any medium or format, as long as you give appropriate credit to the original author(s) and the source, provide a link to the Creative Commons licence, and indicate if changes were made. The images or other third party material in this article are included in the article's Creative Commons licence, unless indicated otherwise in a credit line to the material. If material is not included in the article's Creative Commons licence and your intended use is not permitted by statutory regulation or exceeds the permitted use, you will need to obtain permission directly from the copyright holder. To view a copy of this licence, visit http://creativecommons. org/licenses/by/4.0/.

\section{References}

Ahuja I, Løes AK (2019) Effect of fish bones and algae fibre as fertilisers for ryegrass. NORSØK Rep 4(7) 2019, 64p. http://orgprints.org/36439/ 
Battock M, Asam-Ali S (1998) Fermented fruits and vegetables. A global perspective. FAO Agricultural Services Bulletin No 134. http://www.fao.org/3/x0560e00.htm\#con

Blythman J (2018) The Quorn revolution: the rise of ultraprocessed fake meat. The Guardian, February 12, 2018. https://www.theguardian.com/lifeandstyle/2018/feb/12 /quorn-revolution-rise-ultra-processed-fake-meat

Bosschaert T (2001) Merredin health industries Spirulina plant. Except, Utrecht http://www.except.nl/en/projects/77merredin-health-industries-spirulina-pla

Caporgno MP, Mathys A (2018) Trends in microalgae incorporation into innovative food products with potential health benefits. Front Nutr 5:58. https://doi.org/10.3389 /fnut.2018.00058

Cooper J, Reed EY, Hörtenhuber S, Lindenthal T, Løes AK, Mäder P, Magid J, Oberson A, Kolbe H, Möller K (2018) Phosphorus ability on many organically managed farms in Europe. Nutr Cycl Agroecosyst 110:227-239. https://doi. org/10.1007/s10705-017-9894-2

Dion PP, Jämtgård S, Bertrand A, Pepin S, Dorais M (2018) Organic nitrogen uptake and assimilation in Cucumis sativus using position-specific labeling and compound-specific isotope analysis. Front Plant Sci 9:1596. https://doi.org/10.3389 /fpls.2018.01596

Esbroek E (2018) Temperature control of microalgae cultivation under variable conditions. MSc thesis Biobased chemistry and technology. Wageningen University and Research, Wageningen. https://edepot.wur.nl/455088

Khan MI, Shin JH, Kim JD (2018) The promising future of microalgae: current status, challenges, and optimization of a sustainable and renewable industry for biofuels, feed, and other products. Microb Cell Factories 17:36. https://doi. org/10.1186/s12934-018-0879-x

Kowitt E (2017) The future of food production will look a lot like brewing beer. https://fortune.com/2017/03/20/food-techfermentation-yeast/

Løes AK (2017) Laying hens for soil fertilization. NORSØK Rep 2(13) 2017, 31p. http://orgprints.org/32518/
Løes AK, Adler S (2019) Increased utilisation of renewable resources: dilemmas for organic agriculture. Org Agric 9:459 469. https://doi.org/10.1007/s13165-018-00242-2

Lundquist TJ, Woertz IC, Quinn NWT, Benemann JR (2010) A realistic technology and engineering assessment of algae biofuel production. Report, Energy Biosciences Institute, University of California, Berkeley. 178 . https://digitalcommons.calpoly.edu/cenv fac/188/

Lupatini AL, Colla LM, Canan C, Colla E (2017) Potential application of microalga Spirulinaplatensis as a protein source. $\mathrm{J}$ Sci Food Agric 97:724-732. https://doi.org/10.1002 /jsfa.7987

Möller K, Oberson A, Bünemann EK, Cooper J, Friedel JK, Glæsner N, Hörtenhuber S, Løes AK, Mäder P, Meyer G, Müller T, Symanczik S, Weissengruber L, Wollmann I, Magid J (2018) Improved phosphorus recycling in organic farming: navigating between constraints. Adv Agron 147: 159-237. https://doi.org/10.1016/bs.agron.2017.10.004

Øverland M, Skrede A (2017) Yeast derived from lignocellulosic biomass as a sustainable feed resource for use in aquaculture. J Sci Food Agric 97:733-742. https://doi.org/10.1002 /jsfa. 8007

Rahmann G, Grimm D, Kuenz A, Hessel E (2019) Combining land-based organic and landless food production: a concept for a circular and sustainable food chain for Africa in 2100 . Org Agric 10:9-21. https://doi.org/10.1007/s13165-01900247-5

Rittl T, Krogstad T, Eikås S, Saltnes T, Sørensen G, Glestad HE, Løes AK (2019) Effects of struvite application on soil and plants: a short-term field study. NORSØK Rep 4(10) 2019, 38 p. http://orgprints.org/36472/

Slade R, Bauen A (2013) Micro-algae cultivation for biofuels: cost, energy balance, environmental impacts and future prospects. Biomass Bioenergy 53:29-31. https://doi.org/10.1016 /j.biombioe.2012.12.019

Publisher's note Springer Nature remains neutral with regard to jurisdictional claims in published maps and institutional affiliations. 